SJ Quinney College of Law, University of Utah Utah Law Digital Commons

Environmental Dispute Resolution Program

Wallace Stegner Center for Land, Resources, and the Environment

$4-1-2013$

\title{
Uinta Basin: Elevated Ozone Creates Opportunities, Not Adversaries
}

John Robinson Jr.

Utah Office of the Attorney General

Follow this and additional works at: http://dc.law.utah.edu/edr

Part of the Law Commons

\section{Recommended Citation}

Robinson, John Jr., "Uinta Basin: Elevated Ozone Creates Opportunities, Not Adversaries" (2013). Environmental Dispute Resolution Program. 11.

http://dc.law.utah.edu/edr/11

This Article is brought to you for free and open access by the Wallace Stegner Center for Land, Resources, and the Environment at Utah Law Digital Commons. It has been accepted for inclusion in Environmental Dispute Resolution Program by an authorized administrator of Utah Law Digital Commons. For more information, please contact valeri.craigle@law.utah.edu. 


\section{Student Conflict Assessments}

Students taking Environmental Conflict Resolution conduct a conflict assessment based on a student-selected real-life environmental or natural resource conflict. They analyze the nature, source and history of the conflict, identify potential stakeholders and potential issues. If the conflict is, or has been, subject to a dispute resolution process, the student writes a case study identifying best practices and lessons learned, and gives suggestions of what could have been done differently and why (looking back). If the conflict is not currently, and has not been, subject to a dispute resolution process, the student designs a dispute resolution process (looking forward). Some students do a combined case study and future process design.

Students' papers posted on the EDR Program website include an Executive Summary. For case studies (looking back), this highlights the best practices and lessons learned. For dispute resolution process designs (looking forward), this provides a summary of the essential process components. The primary purpose of posting these student assessments is to disseminate the "best practices" and "lessons learned" in each paper.

\section{Disclaimers:}

- The assessment reports reflect the student authors' opinions, and do not reflect the views or opinions of the University of Utah, any of its affiliated entities, or any individuals interviewed as part of the assessment.

- Unlike a conflict or situation assessment conducted by a professional third party neutral, the students' work does not include interviews of all stakeholder interests. While every attempt has been made to include the full range of perspectives in the analysis, it is possible that some perspectives have been omitted.

- The assessment reports are posted as they were written by the students and therefore reflect a snapshot-in-time. Facts and perspectives can change; for ongoing conflicts, the reader is encouraged to do additional research to confirm that the situation described in the assessment remains current.

- For questions about factual issues, the reader is encouraged to refer to underlying resource documents. 
Uinta Basin: Elevated Ozone Creates Opportunities, Not Adversaries

John Robinson Jr., April 2013 - Page 2

\title{
UINTA BASIN: \\ ELEVATED OZONE CREATES \\ OPPORTUNITIES, NOT ADVERSARIES
}

\author{
John Robinson $J r^{*}$
}

April 2013

$* * *$

\begin{abstract}
This paper examines rural ozone pollution in the Uinta Basin. The pollution issue is complex-scientific uncertainty compounds with jurisdictional issues under the Clean Air Act. A large number of conservation, government, and economic stakeholders take interest in the region's air quality and there are no easy answers. This paper seeks to stimulate discussion in hopes of fostering a collaborative approach to solving the problem. It includes both a conflict assessment and proposes a process design for moving forward through cooperation.
\end{abstract}

* (C) John Robinson Jr., J.D. 2014, The University of Utah College of Law; B.S. 2001, The University of Maine. John is currently O'Hara Honors Fellow in Natural Resources Law at the Utah Office of the Attorney General (as of August 2014). This Assessment was written while the author was a J.D. Candidate, University of Utah S.J. Quinney College of Law. Thank you to everyone who answered my questions along the way. All errors belong to the author. 


\section{Uinta Basin: Elevated Ozone Creates Opportunities, Not Adversaries \\ John Robinson Jr., April 2013 - Page 3}

\section{Table of Contents}

Introduction 4

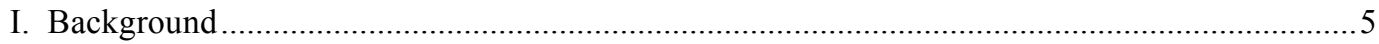

A. The Clean Air Act: A Simple Overview and Why It Matters ....................................6

B. Uinta Basin's Geography and Economy.................................................................... 8

C. History and Formation of Ozone in the Uinta Basin .................................................. 10

II. Current Collaborative Process ............................................................................................ 12

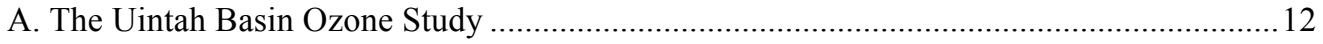

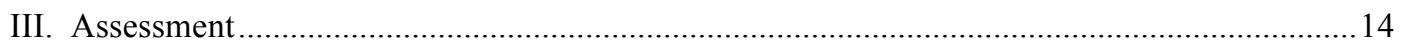

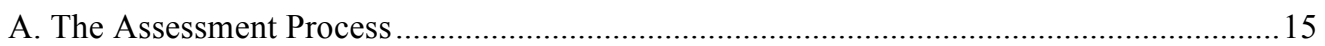

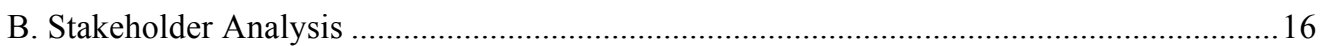

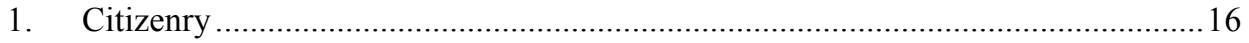

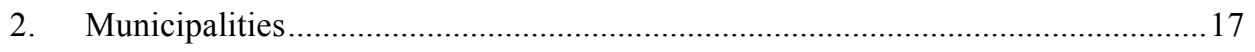

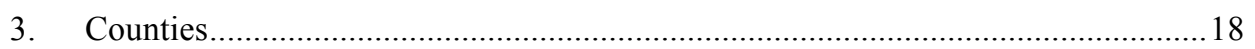

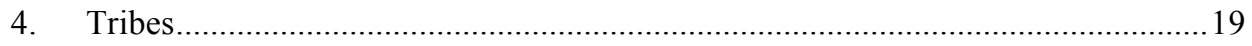

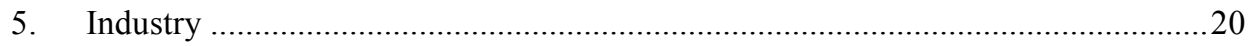

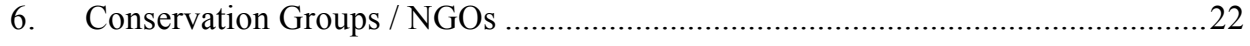

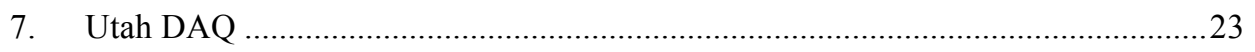

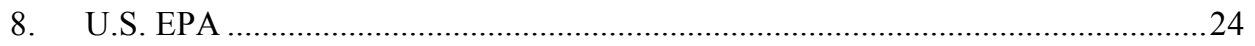

9. Bureau of Land Management .......................................................................26

C. Potential Conflicts Surrounding an Ozone Collaboration …......................................27

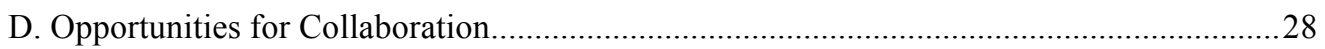

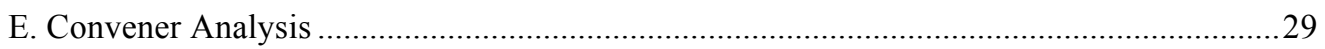

IV. Process Design: Uinta Basin Ozone Prevention Coalition ..................................................30

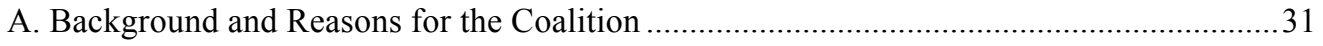

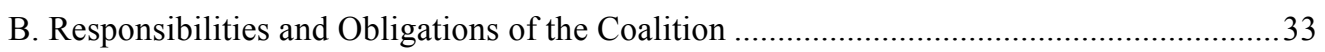

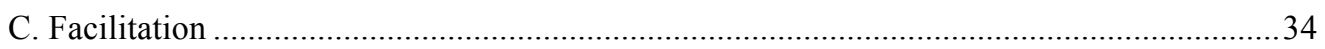

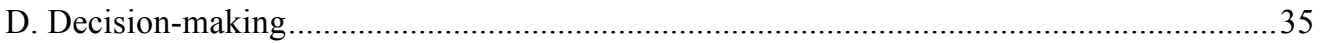

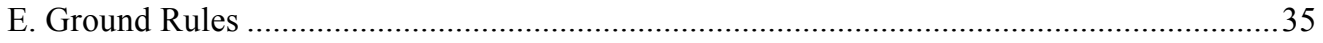

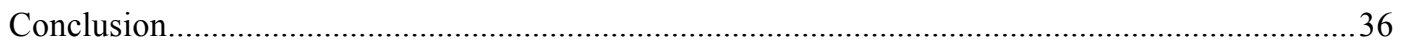




\section{INTRODUCTION}

Generally, mention of "ozone" conjures images of either aerosol cans burning a hole in the earth's protective layer or a smoggy Los Angeles summer. Both are accurate in their own way, but the two data points create only part of the ozone-problem spectrum. That spectrum broadened in Utah during the winter of 2009 , when air quality monitors first detected elevated wintertime ozone concentrations in the Uinta Basin.

The discovery of elevated ozone came as some surprise to most interested parties in the area, even though an earlier discovery in Wyoming put the region on notice. Several winters earlier, monitors in the Upper Green River Basin of Wyoming, a geographically similar region with heavy oil and gas development, detected high ozone.

Corroboration of the Green River's observed ozone data in the similar but distinct Uinta Basin prompted scientists to reconsider their notions of ground-level ozone. The ozone pollution spectrum no longer consisted strictly of summer weather in highly urbanized locales - it now included winter weather in extremely remote places.

Those interested in the Basin's economy and human health, from county commissioners, to local citizens, to extractive industries, suddenly face a major problem. On the one hand, ozone presents a major threat to human health, especially for children and the elderly. ${ }^{1}$ On the other, current science knows comparatively little about rural ozone formation or how to mitigate it. $^{2}$

${ }^{1}$ Even low levels of ozone cause health effects, and some individuals are more susceptible to impacts than others. Worldwide, ozone accounts for almost three-quarters of a million premature deaths each year. Ainsworth et al., Ozone and Net Primary

Productivity, 63 AnNu. ReV. Plant Biol. 637, 639 (2012).

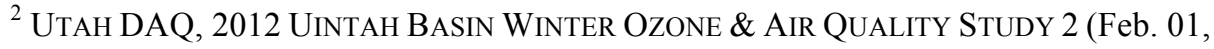
2013), available at http://rd.usu.edu/files/uploads/ubos_2011-12_final_report.pdf [hereinafter OzONE STUDY]. 
After several winters and millions of dollars, regulators and concerned citizens know enough about the ozone problem to move forward. Because the EPA has not yet designated the Basin as "nonattainment,"3 a window of opportunity exists for stakeholders to forge collaborative relationships and get ahead of the curve. Failing to do so will jeopardize public health and almost certainly lead to a nonattainment designation, the ramifications of which place an onerous burden on the oil and gas industry and, therefore, the local economy.

This paper proceeds in four parts. Part I consists of background material, including: a simple overview of the Clean Air Act; the economics and geography of the Uinta Basin; and a brief look at the history and formation of ozone in the Basin. Part II takes a brief look at the current state of collaborative efforts addressing the ozone pollution. Then, part III presents a conflict assessment, including stakeholder analysis as well as opportunities for, and challenges facing, collaboration. Finally, part IV proposes one potential collaborative process design. The suggested process incorporates the many stakeholders into a problem-solving team for the purpose of proactively managing the conflict in a mutually beneficial and widely-supported manner.

\section{BACKGROUND}

Part I of this paper assesses the current status of Uinta Basin air quality issues, specifically the elevated wintertime ozone levels within the region. First, the paper presents a broad overview of the Clean Air Act (CAA) in subpart $\mathrm{A}$. The CAA is major congressional legislation, and under it the

\footnotetext{
3 "Nonattainment" is U.S. EPA's term of art for a region that does not meet national ambient air quality standards (NAAQS). The EPA Administrator sets these standards at a level "allowing an adequate margin of safety ... to protect the public health." Clean Air Act $\S 109$ (b)(1).
} 
EPA promulgates federally-mandated air quality standards that Utah must enforce. This section also explains the connection between the CAA and ozone pollution in the Basin. Subpart B then presents a simple background picture of the Uinta Basin's geography and economic footprint. Finally, subpart $\mathrm{C}$ presents a brief history of rural ozone in the Basin as well as the mechanics of its formation.

\section{A. The Clean Air Act:}

\section{A Simple Overview and Why It Matters}

The Clean Air Act (CAA) exists to protect and enhance the quality of the Nation's air resource and to promote the public health and welfare. ${ }^{4}$ To achieve this goal, Congress tasked the U.S. Environmental Protection Agency (EPA) with establishing and enforcing national regulations. However, the CAA left states with the primary responsibility to prevent air pollution. ${ }^{5}$ In modern terms, this relationship is known as "cooperative federalism," and is a framework within which the federal government provides leadership and guidance, but leaves on-the-ground work to the various states. ${ }^{6}$ This feature allows flexibility for planning at a regional level.

The CAA is widely considered the most complicated and comprehensive legislation in the United States, but only a handful of its mechanisms relate directly to wintertime ozone in the Basin. First, EPA determines a list of "criteria pollutants"-pollutants with wide dispersion around the country that pose a risk to human health. At this time, there are six criteria pollutants, of which ozone is one. ${ }^{7}$ EPA then sets National

\footnotetext{
${ }^{4}$ Clean Air Act $\S 101(b)(1)$.

${ }^{5}$ Clean Air Act $\S \S 101(\mathrm{a})(3)-(4)$.

${ }^{6}$ See id. § 101(a)(4).

${ }^{7}$ U.S. EPA, National Ambient Air Quality Standards, http://www.epa.gov/air/criteria.html (last visited March 11, 2013).
} 
Ambient Air Quality Standards (NAAQS) for each pollutant using healthbased standards. The NAAQS are based on the best-available scientific data, and are designed to protect human health by an "adequate margin of safety." 8

Currently, EPA lists the ozone NAAQS threshold at 75 parts per billion (ppb). ${ }^{9}$ EPA classifies airsheds that exceed this baseline number as "nonattainment" areas. However, EPA adjusts the NAAQS periodically based on an updated scientific record - the ozone NAAQS is currently under review and EPA will almost certainly reduce it to the range of 60-70 ppb during 2013. ${ }^{10}$ Of course, a lower NAAQS means not only that compliance is more difficult, but also that ozone is more hazardous to health than previously thought.

The final piece of the regulatory puzzle is called a State Implementation Plan (SIP), which is both a central document and the mechanism through with a state controls and monitors air pollution. ${ }^{11}$ Within a given SIP, the state retains a large degree of autonomy to address air quality in whichever way it wants, as long as it provides adequate funding and proper enforcement authority.

If a particular airshed's ozone concentration breaks the NAAQS

${ }^{8}$ Clean Air Act $\S 109(\mathrm{~b})(1)$.

${ }^{9}$ U.S. EPA, National Ambient Air Quality Standards, http://www.epa.gov/air/criteria.html (last visited March 11, 2013).

${ }^{10}$ The draft ozone rule, promulgated in 2011, stated that "EPA is setting the level of the 8-hour standard at 0.070 parts per million." US EPA, Draft National Ambient Air Quality Standards Preamble for Ozone, Oct. 3, 2011, http://www.epa.gov/glo/pdfs/201107_OMBdraft-OzoneNAAQSpreamble.pdf. Some observers think a lower number is possible or likely. See John R. Jacus \& Denee A. DiLuigi, Go West Young Man? Air Quality Developments Affecting Western Oil and Gas Exploration and Production, 24 NAT. RESOURCES \& ENV'T 20, 20 (2010) (stating that EPA will lower the NAAQS for ozone to $0.060-0.070 \mathrm{ppm}$ ).

${ }^{11}$ SIP guidelines are found at Clean Air Act $§ 110(a)(2)$. 
threshold, then EPA designates that region as a "nonattainment" area. In such cases, a rather strict set of regulations attach - the state must make active and substantial steps towards reducing pollution and bringing the airshed back into "attainment."

This delineation, between attainment and nonattainment, is the hook that attaches the Clean Air Act to the Uinta Basin ozone pollution problem. Basically, the State of Utah and other stakeholders have unfettered opportunity to act (or not, as they will) before EPA designates the Uinta Basin as nonattainment. If and when EPA makes the nonattainment determination, however, the Clean Air Act's regulatory requirements drastically affect each stakeholder's interests. Essentially, a nonattainment designation will switch any activity from proactive to reactive in nature.

\section{B. Uinta Basin's Geography and Economy}

The Uintah Basin is rural and geographically isolated, and the economy is dominated by the oil and gas industry $(O \& G)$. While the Uinta Basin holds only slightly more than 50,000 residents, ${ }^{12}$ it is the most significant oil and gas field in Utah. ${ }^{13}$ In fact, it is one of the largest producers within the Rocky Mountains. ${ }^{14}$ The prominent extractive industry accounts for half

\footnotetext{
${ }^{12}$ For purposes of this paper, the Uinta Basin includes Uintah County and Duchesne County. Naturally, geographic regions do not follow political boundaries directly, but in this case the two counties are a close fit. Population figures are from the 2010 census. U.S. Census, State \& County QuickFacts, http://quickfacts.census.gov/qfd/states/49000.html (last visited March 10, 2013).

${ }^{13}$ BurEau OF ECONOMIC AND BUSINESS RESEARCH, THE STRUCTURE AND IMPACT OF UTAH'S OIL AND GAS EXPLORATION AND PRODUCTION INDUSTRY 8 (University of Utah, 2009), available at
}

http://governor.utah.gov/publiclands/PLPCOStudies/Oil\%20\&\%20Gas\%20Economic\%20I mpact_July.pdf.

${ }^{14} I d$. 
of the region's jobs and $60 \%$ of the economy. ${ }^{15}$

The state-wide importance of energy within the Basin is hard to overstate. In $2008,69 \%$ of the Utah's oil production and $68 \%$ of its gas production came out of the Basin. ${ }^{16}$ Even during the economic downturn, double-digit job growth continued in the Basin. ${ }^{17}$ Currently, the Basin accounts for roughly $83 \%$ of Utah's O\&G development. ${ }^{18}$

That being said, the Basin area does cycle through boom and bust with some regularity. ${ }^{19}$ Resource exploitation such as fur trapping, Gilsonite mining, ${ }^{20}$ and oil drilling have fueled the past booms. The fragile and undiversified economy generally turns from boom to bust as demand wanes. That the area is currently experiencing a boom cycle informs local politics-few in the area are keen to return to a bust cycle. ${ }^{21}$

${ }^{15}$ Nick Snow, First Uinta Basin Ozone Formation Study Released, OIL \& GAS Journal (Feb. 20, 2013) (quoting Uintah County Commissioner Mike McKee).

${ }^{16}$ Bureau OF ECONOMIC AND Business RESEARCH, THE StruCture AND IMPACt OF UTAH's OIL AND GAS EXPLORATION AND PRODUCTION INDUSTRY 11-12 (University of Utah, 2009), available at http:/governor.utah.gov/publiclands/PLPCOStudies/Oil\%20\&\%20Gas\%20Economic\%20I mpact_July.pdf.

${ }^{17} \mathrm{Id}$.

${ }^{18}$ As measured by number of wells drilled. Id. at 12.

${ }^{19}$ See Craig Fuller, Uinta Basin, in UtAH History EnCYClOPEDIA (2013), http://historytogo.utah.gov/utah_chapters/the_land/uintabasin.html.

${ }^{20}$ Gilsonite is the trade name for a naturally-occurring form of asphalt located within the Uinta Basin.

${ }^{21}$ Such a proposition is hard to support, but seems a reasonable interpretation given the economic climate, general human nature, and the media coverage. See, e.g., Google search for "Uinta Basin boom transportation" (resulting in a number of articles about transportation issues within the Basin, all of which assume that the "boom" is a good thing). 


\section{History and Formation of Ozone in the Uinta Basin}

Awareness of rural ozone problems in O\&G regions crept into scientific awareness only recently, when air-quality monitors in the Upper Green River Basin of Wyoming (UGRB) detected elevated ozone. Although the Uinta Basin is similar to the URGB in many ways, monitoring there did not detect elevated ozone until somewhat later. In fact, Utah DAQ monitored wintertime pollution in the Basin during the 2007 and 2008 season but did not see any elevated ozone at that time. ${ }^{22}$ According to the officials involved, DAQ directed its first studies at particulate matter (PM2.5). During the first two winters of monitoring, ozone concentrations approached - but did not exceed - the NAAQS. Therefore, DAQ assumed that ozone concentrations did not require immediate action.

During the winter of 2009-10 however, monitoring data spiked drastically. EPA installed new monitoring equipment at Ouray, and DAQ \& EPA watched ozone concentration exceed the NAAQS sixty-eight times during that winter. ${ }^{23}$ On three occasions, ozone concentrations reached close to twice the threshold. ${ }^{24}$ During this time period, EPA also reduced the ozone NAAQS. ${ }^{25}$ So, the ozone problem focused swiftly—not only did ozone pollution spike, but the safe threshold decreased.

The exact and complex causes of wintertime ozone are still under investigation, but a basic understanding has emerged over the last few years. Like summer formation in urban areas, rural ozone forms through a

${ }^{22}$ See OZONE STUdY, supra note 2.

${ }^{23}$ Scott Streater, Air Quality Concerns May Dictate Uintah Basin's Natural Gas Drilling Future, New York Times (Oct. 1, 2010), http://www.nytimes.com/gwire/2010/10/01/01 greenwire-air-quality-concerns-may-dictateuintah-basins-30342.html?pagewanted=all.

${ }^{24} I d$.

2573 Fed. Red. 16,436 (March 27, 2008) ("With regard to the primary standard for O3, EPA is revising the level of the 8 -hour standard to 0.075 parts per million (ppm)"). 
complex photochemical reaction involving volatile organic compounds (VOCs) and nitrous oxides $\left(\mathrm{NO}_{\mathrm{x}}\right)$. Sunlight drives this reaction, and reactivity increases with high temperatures - a primary reason that scientists consider ozone a summer problem. ${ }^{26}$

In the absence of high temperature, the Basin's unique geography plays an essential role in ozone formation. The Basin is essentially a giant bowl ringed by mountains. In periods of high pressure during winter, when snow covers the ground, stagnant air conditions create intense temperature inversions. That is, warm air aloft traps a thin layer of cold air close to the ground. This trapped layer is subject to very little atmospheric mixing, so little opportunity exists for pollution to escape the confines of the basin. ${ }^{27}$ These inversion periods last from days to weeks, and cars, homes, businesses, and petroleum infrastructure pump more ozone constituents into the air all the while.

This phenomenon is not unlike using a can of spray paint in a garage with the doors and windows closed. Spraying a puff or two may not cause much harm, but emptying the whole can leads to serious health consequences. During winter, storms move over the Basin from time to time - they push out the inversion and associated build-up of chemicals, just as opening the windows and doors in the garage clears out the paint fumes.

Snow cover is also essential to winter ozone formation. Because the sun sits at a lower angle in the sky, and the winter temperatures plunge far below summer expectations, the reaction of VOCs with NOx requires an extra boost of energy. In the Basin, this extra energy comes from the sun's reflection off the white snow, a circumstance that effectively doubles the amount of solar energy present for ozone formation. ${ }^{28}$ These unique features

\footnotetext{
${ }^{26}$ See OzONE STUdy, supra note 2, at 1-2, 9 .

${ }^{27}$ Id.

${ }^{28}$ Id. at 9 .
} 
are precisely why ozone pollution control in the Basin may require a regional problem-solving approach.

\section{Current Collaborative Process}

An ongoing collaborative process is taking place within the Uinta Basin. The current process, however, focuses on data gathering, monitoring, and scientific study. At this time, no group is making broadly-supported suggestions for solving the pollution problem. This section sets forth a brief overview of the current process, which provides useful information on the breadth of interests that are already working together, albeit in a researchonly capacity.

\section{A. The Uintah Basin Ozone Study}

The Uintah Basin Ozone Study ${ }^{29}$ (UBOS) of 2011-2012 is the most comprehensive scientific assessment of the Basin to date. ${ }^{30}$ Principally, the study aimed to increase understanding of the relationship between changes in precursor emissions and the resulting ozone concentration. ${ }^{31}$ Among the several objectives of the study, the most relevant to this paper is the goal to "provide information that leads to the development of effective mitigation strategies." 32

The 2012 UBOS cost $\$ 5.5$ million dollars, ${ }^{33}$ and a diverse group funded the project. The funding came from federal agencies such as the National Oceanic and Atmospheric Administration, the National Science Foundation, the Department of Energy, and the Environmental Protection Agency. At

${ }^{29}$ OZONE STUDY, supra note 2.

${ }^{30}$ Cracking the Ozone Code, DAQ.UTAH.GOV (March 7, 2013), http://www.deq.utah.gov/Issues/topics/ozone/index.htm.

${ }^{31}$ UTAH DAQ, OZONE STUDY, supra note 26, at 1.

${ }^{32}$ Id. at 1 (emphasis added).

${ }^{33}$ Cracking the Ozone Code, supra note 30. 
the state level, Utah DEQ, the affected counties, and the Utah School and Institutional Trust Lands Administration contributed finances. Finally, the industry group Western Energy Alliance took part. ${ }^{34}$

Utah DEQ, along with BLM, provided study management and coordination for the UBOS. ${ }^{35}$ An oversight team, including representatives from Western Energy Alliance, EPA, BLM, Utah DEQ, and the Uintah Impact Mitigation Special Service District provided additional guidance. ${ }^{36}$ Finally, a science steering committee with representatives from EPA, Utah DEQ, NOAA, Western Energy Alliance, and two universities provided scientific guidance.

Essentially, the UBOS consisted of a number of smaller individual studies, each of which proceeded somewhat compartmentalized from the others. The UBOS itself is a compilation of the various different projects that occurred over the winter of 2011-2012. As such, the UBOS represents a foundation on which future collaboration might be based. However, that foundation is limited in scope. For the most part, the UBOS partnership focused on scientific working relationships, with few other trappings of a collaborative process. One valuable exception, however, was the community outreach led by NOAA scientists. Under this program, the scientists took some of their sophisticated instruments and conducted demonstrations at local schools. ${ }^{37}$ This information-sharing model might serve as a good example for future collaborative processes.

Although scientific working relationships may form the basis for future problem-solving relationships, the UBOS itself only tackled the informational aspects of ozone pollution. The study generally resulted in a

\footnotetext{
${ }^{34}$ UTAH DAQ, OZONE STUDY, supra note 26, at title page.

${ }^{35} \mathrm{Id}$. at 7 .

${ }^{36} I d$. at 7.

${ }^{37}$ Id. at Fig.5B-13, 5B-14 and accompanying text.
} 
call for more study. That is, even though scientific understanding of the problem progressed significantly as a result of this work, the scientists involved did not make discrete recommendations about mitigation techniques. Therefore, the UBOS partnership cannot provide a functional example of how future pollution mitigation collaboration should proceed.

\section{ASSESSMENT}

The rural and industry-dominated character of the Uinta Basin informs much of the assessment in this paper. Understanding that background, addressed infra part I.C, is essential to assessing and anticipating the needs and interests of the local stakeholders, from local citizens to county officials. Some observers take the position that the Basin's economic importance, as compared to its political influence, leave it ripe for exploitation. That is, the population of the area is so small that citizens do not have the political leverage to push back against state regulators or $O \& G$ special interests. Other observers disagree about any perceived exploitation, suggesting instead that industry interests parallel those of the Basin's residents-economic stability and O\&G development are inextricably linked.

Based on these observations, this paper suggests that coalition building, and an eventual collaborative process, require consideration of all stakeholder interests - both for and against development, no matter the relative power or influence of the stakeholder. Building on that base understanding, this part of the paper proceeds by describing the author's assessment process, including the interviews and techniques involved. It then presents a discrete analysis of many of the stakeholders with interest in solving the Uinta Basin's ozone pollution problem. Finally, this part presents potential sources of conflict, opportunities for collaboration, and a convener analysis. 


\section{A. The Assessment Process}

In preparation for this paper, the author conducted both traditional and non-traditional research. The traditional methods consisted of legal research that built, in part, on the author's previous work exploring the Clean Air Act and the Uinta Basin ozone pollution. Much of the research for the current paper dealt specifically with the jurisdictional and non-technical aspects of the Uinta Basin's air pollution, neither of which were the focus of the previous work. Other traditional research included online and database searches of relevant media coverage, which the author used to build a more complete and nuanced understanding of the political climate of the region.

Much of the stakeholder analysis, including opportunities and challenges, results from personal interviews, email communications, and phone conversations with various interested persons. Each contact's perspective added new light to the issues surrounding the pollution problem, and each contact holds some close association with the area. The author conducted personal interviews with two state employees at Utah Department of Air Quality. In addition, he conducted a phone interview with tribal counsel for the Ute Indian Tribe. Finally, the author conducted a number of email interviews with three conservations groups: Southern Utah Wilderness Alliance, Utah Physicians for a Healthy Environment, and Living Rivers. Additional email interviewees included the Bureau of Land Management and a Clean Air Act lawyer and Denver professor who worked with the Ute Tribe in the past.

The author also reached out to a business group affiliated with the area and to the Ute Tribe itself, but did not receive a timely response from either group. Assuming a more thorough and extended analysis in the future, input from both these groups will be instrumental to painting a complete picture of the Uinta Basin air quality debate. It may be that the Ute Tribe prefers to speak through its tribal counsel and that local businesses feel sufficiently represented by other stakeholder groups. However, both groups should be 
approached directly on this matter.

Further, a future analysis should include direct observation wherever possible, a component that the timeframe and scope of this paper did not allow. Attending public meetings and conservation group functions should be undertaken along with any rulemaking or administrative proceedings. Watching some of these encounters will provide valuable insight into the interests of the respective groups. Also, witnessing how some of these groups interact with each other will prove invaluable for designing an effective collaborative process moving forward.

\section{B. Stakeholder Analysis}

\section{Citizenry}

The inhabitants of Uintah and Duchesne counties live over a large geographic area. Because of the dispersed nature of human habitation across the region, major differences in interest likely exist among this group - the citizenry are not necessarily homogenous. However, the EPA's primary task under the CAA requires protecting human health. Therefore, the needs of the Basin's citizens are, in many ways, paramount to other interests.

Because of the non-diverse nature of the economy in the region, citizens will likely align themselves closely with their economic ties. Further, residents are probably similar in many ways to their counterparts in Cache County, where locals often clash with state and federal officials over air quality. ${ }^{38}$ The general stereotype of these residents is that they look askance at government interference, particularly when federal in nature.

The distrust of government felt by some citizens means that some are

${ }^{38}$ See, e.g., Judy Fahys, Utah's Pollution Plan Moves on Despite Resistance, THE SALT LAKE TRIBUNE (Dec. 25, 2012), http://www.sltrib.com/sltrib/politics/5483350790/county-emissions-epa-lake.html.csp (quoting a Cache County councilman calling CAA regulations a "sledgehammer approach"). 
likely to be wary of interactions with "outside" (particularly federal) representatives and officials. In approaching a coalition building process, it may be best to work through a proxy, such as the Vernal Chamber of Commerce, or some other organization that appears neutral.

If the citizen group is not part of a collaborative resolution to the ozone pollution, then the process risks alienating the very population that the Clean Air Act was meant to protect. In such a case, residents of the area might resort to the citizen suit provision of the CAA. The provision allows individuals to seek enforcement (or judicial review) against EPA or the State of Utah.

\section{Municipalities}

The sparsely populated Uinta Basin includes only a handful of significant towns. Of those, Vernal and Roosevelt (the county seats, respectively, of Uintah and Duchesne Counties) are the most significant. Both are home to roughly $33 \%$ of their county's population.

According to some reports, many of the concerns that municipalities voice revolve around their geographical location compared to the oil \& gas producing areas. For instance, the highest ozone concentrations occur in the center of the Basin, where Vernal lies on the edge. Therefore, the city may or may not be subject to the same elevated levels of ozone as those reported in oil and gas country.

Part of this unease rests on scientific principles. Any scientific research rests on a foundation of assumptions, such as where to place an air quality monitor. In an urban environment, a scientist can be highly confident that any given monitor accurately reflects the actual pollution levels that residents are breathing. That same assumption may not be true in a rural environment however - the elevated ozone levels detected at Ouray may have no bearing on ozone exposure in Vernal some twenty-five miles away.

The municipalities have some influence in state government. If not 
included in a collaborative process, they may exercise their political connections to influence discussions. Therefore, it will be more direct to have them at the table. On the other hand, this group may feel that its interests are sufficiently in line with the Counties that they do not need to be a separate stakeholder.

\section{Counties}

Both Uintah and Duchesne counties have three commissioners. ${ }^{39}$ The commissioners form the executive and legislative bodies for their respective counties. $^{40}$ Typically, the county commissioners are heavily involved in O\&G policy within their jurisdictions. For instance, both counties recently joined industry in a lawsuit filed against BLM over seventy-seven leases that were auctioned off, and then retracted. ${ }^{41}$ According to a county commissioner, the suit was more about preventing a bad BLM precedent regarding future oil and gas development than it was about the disputed leases. $^{42}$

Additionally, both counties moved repeatedly to increase the percentage of mineral severance tax returned to the counties where the extraction took place. ${ }^{43}$ Further, Uintah County Commissioner Michael J. McKee recently told the United States House Subcommittee on Energy and Mineral

\footnotetext{
${ }^{39}$ Welcome to Duchesne County, UTAH.GOV,
} http://duchesne.utah.gov/government/commission.html (last visited March 13, 2013); Uintah County, County Commission, http://co.uintah.ut.us/comm/comm.php (last visited March 13, 2013).

${ }^{40} I d$.

${ }^{41}$ Geoff Liesik \& Mary Bernard, Judge Says Utah Counties' Drilling-Lease Lawsuit Too Late, DeSERET News, Sept. 2, 2010, at B02.

${ }^{42}$ See id.

${ }^{43}$ Lezlee E. Whiting, Counties Lobby To Pass Severance Tax Bill In '06, Deseret News, Mar. 28, 2005, at B03 (discussing the failed House Bill 63 in 2005, and the counties' plans to support a similar bill the following year). 
Resources: "I cannot overstate how important the extractive industry is to our communities." 44

Based on such evidence, county officials will most likely continue to be vocal advocates for the economic benefits of $O \& G$ development and, therefore, are important stakeholders in any ozone process. If the counties' interests are not incorporated through a collaborative process, they may resort to litigation or exercise of their considerable political power.

\section{Tribes}

The Ute Tribe is an essential player for any collaborative approach to solving the ozone pollution problem in the Uinta Basin. Tribal land makes up a large portion of the Basin, and O\&G activity on tribal land is even more pronounced than elsewhere. According to some estimates, as much as $70-80 \%$ of VOC emissions may come from tribal land. The tribe is a critical player in any collaborative effort because Utah has no jurisdiction over the sovereign Ute Tribe or over the tribe's land. ${ }^{45}$

The Utes derive much of their income from oil and gas development. According to some observers, the tribe views regulatory differences as a potential competitive advantage. That is, if drilling on tribal land is easier based on lower regulatory hurdles and compliance costs, operators will gravitate towards the Ute reservation, thereby increasing tribal revenues.

The Utes are also interested in protecting public health, as shown by their recent partnership with Wild Earth Guardians in filing a suit against a local polluter. ${ }^{46}$ However, the total Ute population is only $3,157 .^{47}$

${ }^{44}$ Statement of Michael J. McKee, Cong. Testimony (Mar. 19, 2013), 2013 WLNR 680203.

${ }^{45}$ EPA assists the tribe with air quality management, but has not promulgated a Federal Implementation Plan for the Utes.

${ }^{46}$ Jeremy Nichols, Ute Indian Tribe, WildEarth Guardians Join Forces for Clean Air, Public Health in Utah's Uinta Basin, WILDEARTHGUARDiAnS.ORG (April 25, 2012), 
Therefore, economic interests could trump health interests, particularly because short-term benefits often out-compete long-term ones.

An additional point of possible contention is that the Utes have a longstanding dispute with non-tribal law enforcement. The Utes charge that state, county, and city officers engage in an ongoing pattern of harassment against the tribe. ${ }^{48}$ Such ongoing disputes may present an obstacle for building trust between the tribe and other entities.

As a sovereign entity, the Utes have considerable discretion to avoid a collaborative process if they want. However, sources close to the tribe suggest that the Utes are interested both in collaboration and in proactive measures such as enrollment in Ozone Advance.

\section{Industry}

Major oil and gas developers within the Basin include Anadarko, Newfield, Gasco, EOG Resources, and XTO Energy. ${ }^{49}$ Of these, all but Gasco constitute major players-Anadarko, Newfield, EOG, and XTO are all multi-billion dollar companies. ${ }^{50}$ Conversely, Gasco Energy's stock is

http://www.wildearthguardians.org/site/News2?page=NewsArticle\&id=7613\&news_iv_ctr l=1194\#.UUOuWVcQ_1Y.

${ }^{47}$ About the Utes, UTETRIBE.COM, http://www.utetribe.com/ (last visited March 15, 2013).

${ }^{48}$ Geoff Liesik, Uintah Basin oil, gas drilling could be impacted by dispute between counties, Ute Tribe, DeSERET News (Feb. 14, 2012, 9:07 PM), http://www.deseretnews.com/article/865550159/Uintah-Basin-oil-gas-drilling-could-beimpacted-by-dispute-between-counties-Ute-Tribe.html.

${ }^{49}$ According to DAQ, these companies comprise around three-quarters of the operators, and make up the group that responded to Western Energy Alliance's request for a voluntary well-drilling inventory. UTAH DAQ, 2012 UINTAH BASIN WINTER OZONE \& AIR QUALITY STUDY 177 (Feb. 01, 2013).

${ }^{50}$ Based on New York Stock Exchange market capitalization data, retrieved March 15, 2013. 
trading at $\$ 0.05,{ }^{51}$ and it has serious cash-flow problems. ${ }^{52}$

Based on this information, industry interests probably spit roughly along the big player-small player line. That is, Gasco's interests tend towards the short term; if they are not able to solidify their cash-flow problems, bankruptcy is almost certain. On the other hand, the big players hold diverse leases across the U.S., and therefore tend to take a longer view of air pollution in the Uinta Basin. For these big players, long-term goals probably outweigh, or at least balance, immediate cash flow concerns.

According to one observer, the low price of natural gas is slowing development rates within the basin. The current low profit margins may actually be beneficial to collaborative efforts-with gas prices on the rise, the big companies (with cash reserves) can afford to "wait," and work with scientists and regulators to address the ozone pollution. In fact, it may be in their best interests to work on air quality while the market is tight, thereby allowing them to develop more vigorously when the price of natural gas rises.

Another big player-little player difference revolves around capacity and willingness to engage in collaborative problem solving. According to the conservation community, the smaller companies (those with their eggs all in one basket) engage in collaboration to resolve conflicts less often. On the other hand, the larger (diversified) companies are more willing to engage in a give-and-take discussion to solve problems.

One observer noted that the smaller companies seem to take a radically different approach than larger companies, apparently preferring to gamble

${ }^{51}$ NYSE data, retrieved March 15, 2013.

${ }^{52}$ Gasco Energy (GSX) Reports Q4 Loss of \$0.02, Has Going Concern Doubts, STREETINSIDER.COM (March 6, 2013, 4:37 PM), http://www.streetinsider.com/Earnings/Gasco+Energy+\%28GSX\%29+Reports+Q4+Loss+ of $+\$ 0.02,+$ Has + Going+Concern+Doubts/8163174.html. 
with an all-or-nothing approach to full-field development. ${ }^{53}$ Larger companies, however, prefer stability-they are willing to trade some development in exchange for future certainty.

In the absence of a collaborative solution to air quality in the Basin, industry can either take steps on its own to curb the pollution, or wait for EPA and the state to step in with regulations. At that point, industry would need to accept the rules on which they did not collaborate, or challenge the regulations in court.

\section{Conservation Groups / NGOs}

Several regional and national conservation NGOs operate in and around the Uinta Basin. Two important stakeholders, in this regard, are Utah Physicians for a Healthy Environment (UPHE) and Southern Utah Wilderness Alliance (SUWA). Along with Wild Earth Guardians, SUWA and UPHE entered the ozone debate in 2012 when they filed suit, seeking to compel EPA to designate the Basin as nonattainment. ${ }^{54}$

Living Rivers, another interested conservation NGO, also operates in the Basin. They are closely involved with non-traditional extraction permits, particularly oil shale and tar sands, teaming up with such national players as The Sierra Club. ${ }^{55}$ Thus far, Living Rivers's activities have focused on the

\footnotetext{
53 This assessment derives, in part, from the comments of Steve Bloch during a Stegner Center Green Bag presentation. Steve Bloch: Energy Development and protecting Utah's Red Rock Wilderness - Not Inherently Inconsistent Goals, ULAW.TV (Mar. 7, 2013), http://ulaw.tv/videos/steve-bloch-energy-development-and-protecting-utahs-redrock-wilderness--not-inherently-inconsistent-goals/0_wlkaklfu.

${ }^{54}$ Judy Fahys, Ozone pollution targeted in new Uinta Basin lawsuit, SALT LAKE TRIBUNE (July 25, 2012), http:/www.sltrib.com/sltrib/politics/54543532-90/epa-ozonebasin-clean.html.csp.

${ }^{55}$ Brandon Loomis, Utah Oil Shale Permit Now In Limbo, SAlt LaKe TRIBUne (June 26, 2012), http://www.sltrib.com/sltrib/news/54379406-78/permit-living-riversshale.html.csp; Environmental Groups Protest BLM Oil Shale Plan, SALT LAKE TRIBUNE
} 
potential for ground-water pollution in the Basin, but their other interests probably need to be taken into account.

UPHE's main concern in the Basin is protecting human health. However, they are also philosophically opposed to any "rush" to develop oil and gas resources in the Basin. UPHE feels that the State and Governor are pushing for too much development too quickly, and that the inevitable result will be bad air, exacerbated climate change, and longer fossil-fuel dependency. UPHE also notes that the beneficiaries of development number relatively few and economic benefits are near-term only.

If not accounted for in a collaborative process, the conservation groups will make their views known through other avenues-likely, through litigation in the courts.

\section{Utah DAQ}

Utah DAQ, the state agency with primary authority over air quality on non-tribal land in the Basin, often finds itself at a crossroads of sorts. DAQ must implement EPA's Clean Air Act regulations and protect air quality within the state. However, DAQ operates within a state government ranked as the most business-friendly in the country. ${ }^{56}$ Therefore, DAQ faces pressures from all sides.

One of DAQ's primary concerns involves its perception of the Uinta Basin ozone problem. DAQ thinks that only a small window exists within which a truly collaborative process could function. That window might exist

(Dec. 11, 2012), http://www.sltrib.com/sltrib/politics/55445543-90/blm-coloradodevelopment-environmental.html.csp.

${ }^{56}$ Forbes recently ranked Utah best overall, and third best in terms of business-friendly regulatory climates. Kurt Badenhausen, Utah Tops Forbes 2012 List Of The Best States For Business, Forbes.com (Dec. 12, 2012 at 11:56 AM), http://www.forbes.com/sites/kurtbadenhausen/2012/12/12/utah-tops-list-of-the-best-statesfor-business/. 
only as long as EPA does not designate the Basin as nonattainment. According to some officials, most of the important stakeholders may run for the hills if and when that happens. Therefore, DAQ's position is that any collaborative steps must be taken fairly soon - a nonattainment designation could be as near 2014 .

Further, the jurisdictional overlaps within the Basin cause DAQ substantial concern. According to a subjective estimate, as much as $70-80 \%$ of O\&G-related emissions arise on Indian Country, where DAQ has no regulatory power. Essentially, this places DAQ in an untenable positionthey hold primary responsibility for ensuring air quality, but do not have the complete authority with which to do so.

Lastly, DAQ echoed concerns brought up by the O\&G industry. If industry undertakes emissions reduction prior to a nonattainment designation, then these preemptive reductions could actually make future compliance efforts more costly. That is, emission reduction now (prenonattainment designation), using the most cost-effective methods, reduces industry's capacity to cheaply meet future reduction requirements. Basically, the concern is that industry may not get "credit" under the CAA for any action they undertake voluntarily. This concerns DAQ because such a scenario actually incentivizes industry to take a wait-and-see stance. However, Utah's recent entry into EPA's Ozone Advance program significantly mitigates these concerns, as discussed infra at part III.B.8.

Because DAQ holds permitting power and regulatory authority over much of the Basin, they are essential to a collaborative process. If not involved, DAQ could act unilaterally to curb the ozone pollution.

\section{U.S. EPA}

EPA's main job, under the CAA, requires protecting human health. Although one might not know it from many media accounts, EPA remains relatively agnostic as to the fine-grained details. EPA promulgates 
standards, and EPA must approve (and can therefore reject) each state's SIP. However, the CAA's cooperative framework leaves states with a certain measure of flexibility.

In the Uinta Basin, EPA also holds regulatory authority over Indian Country. Therefore, EPA is more directly involved, as a stakeholder, than it would otherwise be. According to some sources (but not confirmed by EPA), the agency is dragging its feet with regard to regulating emissions on Indian Country. Apparently, EPA will not promulgate a Federal Implementation Plan unless and until the Ute Tribe asks them to do so. If true, this situation sets up an impasse. Without emissions reduction on Indian Country, any DAQ regulations will probably be ineffective.

However, this situation does not entirely preclude an effective collaborative solution. That is, O\&G can voluntarily undertake emissions reduction across jurisdictions. In fact, the jurisdictional overlay makes a consensus-based collaboration even more appealing because such solutions avoid jurisdictional problems all together.

A final component of EPA's Basin involvement is the newly-created Ozone Advance program. ${ }^{57}$ It supports states, tribes, and local governments in their work to maintain air quality and keep areas out of nonattainment status. EPA's goals are three-fold: (1) help attainment areas take action in order to keep ozone levels below the level of the ozone NAAQS to ensure continued health protection for their citizens; (2) better position areas to remain in attainment; and (3) efficiently direct available resources toward actions to address ozone problems quickly. ${ }^{58}$

\footnotetext{
${ }^{57}$ Ozone Advance rolled out on April 4, 2012. U.S. EPA, Ozone Advance Memorandum (April 4, 2012), available at http://www.epa.gov/ozoneadvance/pdfs/20120404memo.pdf. For more information, see U.S. EPA, Advance Program, http://www.epa.gov/ozoneadvance/index.html (last visited March 15, 2013).

${ }^{58}$ U.S. EPA, OZONE ADVANCE GUIDANCE 1 (2012), available at
} 
Under this program, O\&G's fears of not getting "credit" for their prenonattainment emissions reductions should be assuaged. ${ }^{59}$ Reductions under Ozone Advance would either result in a lower baseline from which to measure reasonable further progress, or actually be counted as progress towards attainment, in the event that EPA does eventually designate the Basin as nonattainment. ${ }^{60}$ Utah enrolled the Uinta Basin in Ozone Advance on May $21,2012 .{ }^{61}$

EPA holds considerable regulatory power in the abstract, but much of that power flows to DAQ through cooperative federalism. If not part of a collaborative process however, EPA can operate in much the way it often does, as a top-down authority with strong regulatory powers.

\section{Bureau of Land Management}

BLM: Utah manages nearly 23 million acres of land within the State of Utah, and it leases significant amounts of land for resource development within the Uinta Basin. ${ }^{62}$ Predicated on the concept of a "one atmosphere" airshed model, Utah BLM recently developed an Air Resource Management Strategy (ARMS) for its lands. ${ }^{63}$

The ARMS recognizes that pollution does not stop at political boundaries, and sets its goal to "[p]roactively manage air quality and

http://epa.gov/ozonepmadvance/pdfs/2012404guidance.pdf.

${ }^{59} \mathrm{Id}$.

${ }^{60}$ This scenario is of importance because a nonattainment designation is a likely outcome in the Basin, even if collaborative problem-solving takes place.

${ }^{61}$ State of Utah, Uintah Basin Area Sign-up Letter (May 21, 2012), available at http://www.epa.gov/ozoneadvance/pdfs/20120521ut.pdf.

${ }^{62}$ Eg., Bureau of Land Management Approves Uinta Basin Gas Project, BLM.GOV (June 18, 2012), http://www.blm.gov/ut/st/en/info/newsroom/2012/june/bureau_of_land_management.html.

${ }^{63}$ Utah Bureau of LAND Management, Air Resource Management Strategy (ARMS) (July 2011) (on file with author). 
atmospheric values during land management planning ... while maintaining BLM's multiple-use management responsibilities." ${ }^{, 64}$ Within that goal, the ARMS sets forth six objectives. Two of the objectives are particularly relevant to this assessment. Under the ARMS, Utah BLM will: (1) Work collaboratively and in partnerships with others to bring about the best achievable air quality within BLM lands and Utah in general; and (2) promote education and awareness of air resources on BLM lands. ${ }^{65}$

According to one official, the overlapping jurisdictions and dispersed nature of O\&G development mean that working collaboratively is the only way forward in terms of making significant progress. Therefore, Utah BLM is not only an important stakeholder, but also a willing participant in future collaborative problem solving.

\section{Potential Conflicts Surrounding an Ozone Collaboration}

Conflicts over air quality in the Uinta Basin arise from a mixture of substantive issues, positional inflexibility, and procedural hurdles. Even very reasonable substantive results may fail based on an excess of posturing or systemic distrust between groups. Likewise, procedure that lacks enough flexibility to accommodate a proposed action might stymie the effectiveness of collaborative action. Because the stakeholders identified above exist over a broad spectrum of interests and past experiences, understanding the potential conflicts therein will substantially influence the ability for a collaborative process to succeed.

In this case, the conflicts do not seem to be of stark contrast to one another. That is, it is not a black versus white showdown. Appropriately addressed, many of the potential conflicts will involve a balancing act rather than a this-for-that bargaining scheme. Therefore, properly understanding

\footnotetext{
${ }^{64} I d$. at 2.

${ }^{65} I d$. at 2 .
} 
the interests underlying each potential conflict is essential. If one party has a preconceived notion about what another wants, that notion may form the nucleus of a conflict that is tangential to the real issue.

For instance, industry may assume that a conservation group wants to shut down development in the Basin. The conservation group might assume that industry wants to develop the field, no matter what the cost in pollution. This sort of adversarial position overlooks the (in reality) overlapping interests of both groups - the attainment and maintenance of healthy ozone levels.

\section{Opportunities for Collaboration}

The Uinta Basin ozone pollution problem presents a wealth of opportunity for collaboration. In this case, opportunities for collaboration are directly related to the available non-collaborative alternatives. Essentially, all the stakeholders have some mechanism through which to impose their positions and views upon the other groups.

Some of these mechanisms are stronger options than others. For instance, DAQ, EPA and BLM all have varying degrees of regulatory power which they can wield, in many cases, unilaterally. On the other hand, local citizens, municipalities, and counties do not have direct authority over

air quality or O\&G development. Those groups do, however, have access to the political process which is also a powerful tool.

Conservation interests also offer an excellent opportunity for collaboration because these interested groups will almost certainly make their interests known, one way or the other. That is, if conservation interests are not accounted for in the decision-making process, the groups will resort to litigation. Even in a worst-case scenario, litigation often substantially affects the decision process. Essentially, the voice of conservation groups will be heard at some point, whether in the courtroom or in a collaborative process. All stakeholders benefit from the latter option, rather than the 
former.

Industry has many incentives to participate in a collaborative process as well. Particularly under EPA's Ozone Advance program, collaboration poses very limited exposure to risk. If proactive steps lead to decreases in air pollution within the Basin, then industry avoids the increased regulations of a nonattainment designation. If the industry takes proactive steps, and the airshed falls into nonattainment anyway, then industry is already in a better position than if it had done nothing because its proactive steps count as credit under Ozone Advance.

Based on the above, the benefits of a successful collaborative process outweigh the risks of not collaborating. Therefore, the collaborative process offers a significantly increased likelihood of a positive outcome for all stakeholders.

\section{E. Convener Analysis}

Ideally, solving the Uinta Basin ozone pollution problem will begin with a call to form a working group to assess the problem. (One potential process design for such a working group is illustrated infra at part IV.) To initiate such a process, one person or entity should convene the working groupconvene meaning to formally bring the group together. Ideally, this convener will be well respected and have stature in the community.

In this case, a high-ranking elected official may be the best choice. The governor of Utah, for instance, could establish the working group. Because her interests will be represented by the other government stakeholders, such as DAQ, the governor will be able to formally initiate the working group, and then step back from the process. In this way, her influence can "get the ball rolling" without jeopardizing the process through the appearance of undue influence among the stakeholders. That is, this method of convening the working group will decrease the appearance of partisanship.

Regardless of how the working group comes together, the convener 
should offer a training component at the beginning of the collaboration. This training component, among other things, should teach the participants how to behave within the process. For instance, behavior training should include admonitions not to make personal attacks and so on. Additionally, the training process may include mutual education and joint fact-finding. This training period provides an excellent opportunity for on-the-ground learning in the form of field visits. Touring industrial operations, such as active drilling pads, and the scientific monitoring stations are both recommended.

Finally, the convener should present the pollution issue such that it requires a concept or a group of suggestions for an answer. Framing the issue such that it might have a "yes" or "no" answer induces and supports positional, rather than interest-based, negotiation.

\section{Process Design:}

\section{Uinta Basin Ozone Prevention CoALITION}

This part suggests one possible collaborative process, designed to bring multiple stakeholders together with the purpose of defining and proposing solutions to the Uinta Basin's wintertime ozone pollution. This design is based on the background provided above, supra parts I-III, with a particular emphasis on providing a process flexible enough to change dynamically with the needs of the diverse stakeholders represented. The author surveyed a number of other conflict assessments and process designs in the construction of these suggestions. The design below incorporates some elements from other processes, ${ }^{66}$ tailored to the stakeholders, interests, and unique problems associated with wintertime ozone pollution in the Uinta

\footnotetext{
${ }^{66}$ Particularly useful background came from the Ruckelshaus Institute at the University of Wyoming, which facilitated an air quality taskforce organized around similar ozone pollution problems in the Upper Green River Basin of Wyoming.
} 
Basin.

\section{A. Background and Reasons for the Coalition}

Utah DAQ, U.S. EPA, Utah BLM, and the Ute Indian Tribe recognize that elevated ozone levels within the Uinta Basin endanger public health and well-being, and that collaborative problem-solving presents the bestavailable means of protecting air quality and preserving economic stability in the region. Currently, many stakeholders are working together to reach a better scientific understanding of the ozone pollution through monitoring and research efforts. The scientific working relationship represents a launching pad for problem solving under this process design.

Ozone pollution within the Uinta Basin also poses challenges for local residents, businesses, and the civil entities that represent them. Further, the Uinta Basin's resources expand beyond the scope of oil and gas: spiritual value, unique archaeological sites, wilderness, and wildlife all play an extremely valuable role in the Uinta Basin. To that end, pollution and development in the Basin involves a broad community that extends throughout the State of Utah as well as nationally. Therefore, the conservation community and NGOs also play an important role in the planning for the Basin's future.

The primary purpose of the Uinta Basin Ozone Prevention Coalition is to consider a wide array of potential solutions to the elevated ozone levels within the Basin. For these purposes, the Coalition will primarily consider Uintah and Duchesne Counties, which constitute much of the Basin, and are the two political divisions enrolled in EPA's Ozone Advance program. However, air and air quality exist independent of political boundaries, so the Coalition's advice and findings may hold relevance elsewhere.

After due consideration of possible solutions, the Coalition will advise the relevant agencies on those solutions which enjoy a broad base of support across the various stakeholder groups. That is, the Coalition's 
findings and advice will result from consensus among the stakeholders. To accomplish these goals, the Coalition will engage in, and facilitate, mutual education and transparent communication of interests between all interested parties.

The Coalition reports back to the convener and also advises DAQ, EPA, and the Ute Tribe. However, the Coalition's advice does not bind DAQ or any other entity - DAQ will strongly consider such advice among a range of alternatives. It may accept or reject all or portions of any relevant advice generated by the Coalition. However, some of the Coalition's advice may fall outside the scope of DAQ's regulatory power, particularly considering the complex jurisdictional structure within the Basin. ${ }^{67}$

In addition to proposing solutions and generating advice, the Coalition will engage the public with reports and information, thus encouraging transparency and supporting stakeholder buy-in. This public outreach will include providing educational opportunities and leveraging new media such that all applicable constituencies have equal access to information.

The Coalition will consist of twenty-one members and two alternates. Three people will represent each of the stakeholder groups identified, supra, in Part I.E.1-6. Utah DAQ, BLM, and EPA will contribute one representative each. Two alternates will be selected randomly and at-large from the citizens stakeholder group. (Basin residents are most likely to have trouble attending all meetings, whereas other Coalition participants are generally doing this work as part of their employment.)

Each stakeholder group with three representatives will select their own

${ }^{67}$ DAQ holds no authority over the Ute Reservation, which makes up around $17 \%$ of the Basin. Bureau of Economic and Business Research, The Structure and Economic Impact of Utah's Oil and Gas Exploration and Production Industry Phase I - The Uinta Basin 9 (University of Utah 2007), available at http://governor.utah.gov/publiclands/PLPCOStudies/EconomicImpactofO\&GIndustryALL. pdf. 
representatives. The purpose of this feature of the Coalition is maintaining a balanced panel. For instance, the industry representatives should not represent a particular company, but the group of involved companies as a whole. Likewise, the NGO community's representatives should represent the community's interests, not the specific interests of their own organization. Each stakeholder group should select its three-person delegation carefully to maximize chances for positive outcomes while protecting against rogue representation. Further, representatives with preexisting conflicts with other stakeholders should be appointed only after careful consideration.

Each Coalition member will represent the interests of the entity or stakeholder-group that elected them to the Coalition.

\section{B. Responsibilities and Obligations of the Coalition}

Members make a commitment to the objectives of the Coalition and will remain open and honest at meetings. They will disclose their interests and any issues that arise during the Coalition's lifespan. They will conduct themselves in a dignified manner, and they will respect the dignity of other Coalition members even when not in mutual agreement. Through the duration of the Coalition, members will proceed towards the mutual goal of ozone reduction in good faith without sabotaging the process.

Further, each member of the Coalition agrees that active and transparent (where possible, respecting that some interests may be confidential) communication is necessary to positive outcomes. To this end, each member will act as a point person within the stakeholder group that they represent. This means that each member will inform their constituencies of the Coalition's progress and engage that constituency in discussions designed to refine and improve the representative's understanding of constituent interests. In this way, feedback from people, entities, and groups not directly represented on the Coalition will find its way into the 
Coalition's discussion.

Coalition members must attend and participate to the fullest extent possible. Any questions regarding this component should put the associated stakeholders on notice to select a different representative. That being said, the Coalition understands that emergencies and changes in circumstance do occur over the course of negotiations. If circumstances arise that force a representative to miss a meeting or discussion, that representative must take steps to understand any Coalition work undertaken in her absence and record her dissatisfaction (if any) in a timely manner.

\section{Facilitation}

The convener should select two highly qualified facilitators to lead and guide the collaborative process. The facilitators' role consists of coordinating meeting logistics, promoting and maintaining a professional atmosphere consistent with Coalition objectives, keeping the Coalition on task, and so on. In addition, the facilitators will help build consensus among the Coalition by promoting simple and concise expression of suggestions, ideas, and interests.

In this case, two facilitators working in conjunction may provide the best flexibility for the collaboration process. One facilitator should be fluent in the technical aspects of both oil and gas development and Clean Air Act law. This facilitator will be able to help "translate" the complexities of the legal and technical aspects of the discussions into lay terms when necessary. The other facilitator's role should focus more on the logistical aspects of the collaboration process.

Both facilitators will also work between meetings and discussions to ensure that each member's interests and suggestions are being appropriately identified and dealt with. This includes promoting exchange of ideas as well as helping to overcome any roadblocks that might arise. 


\section{Decision-making}

Any advice or suggestion proposed by the Coalition will arise from consensus among the entire group of representatives. In this way, the Coalition may arrive at agreement that represents the interests of all stakeholders-not just an agreement between two parties. Requiring a consensus prevents distortion of the advice presented-consensus is inherently anti-majoritarian. Although all members need not be equally happy with any given suggestion, they must all agree that it is the best possible "agreement" within the confines of the interests and parties involved.

The consensus-based model incorporates many of the facets discussed above, including mutual education and honest communication. To each "point" of discussion, each member will indicate their level of acceptance using a sliding scale. At one end of the scale, the member indicates complete agreement with the point. On the other, the member indicates that they cannot support the point-essentially preventing consensus. In between the two, a member can indicate various levels of agreementmajor or minor concerns about the point.

All votes will be open, and facilitators will call for and count votes during meetings. The sliding scale allows facilitators to gauge the stakeholders and determine how much and what kind of further discussion is necessary. Consensus is reached whenever zero members indicate a veto vote. In the event that consensus cannot be reached on a major point, the facilitators will record the veto and the reasons supporting it. The Coalition can move forward on a point without consensus only when forward progress, in furtherance of the Coalition's goals, so requires.

\section{E. Ground Rules}

All members of the Coalition agree to the following ground rules. Further, they understand that the facilitators' role requires reminding and 
demanding that members adhere to them.

To support forward progress and concise and orderly meetings, members will speak one at a time. No member will dominate others, just as no member will remain totally silent on any point. Each speaker will stay on point. Brevity is the soul of wit.

Speakers will also make every effort to confine their discussion to the topic at hand, to avoid any side conversation that might appear to be partisan in nature, and to treat the other members of the Coalition with civility and respect. To this end, common courtesy applies. Members should not interrupt one another, speak over one another, or convey hostility. Although humor can sometimes relieve tension, members will refrain from using humor or sarcasm at the expense of another member or interest.

\section{CONCLUSION}

Wintertime ozone pollution in the Uinta Basin presents a complex challenge to human health, economic stability, and the regulatory regime. The complexity derives not only from a very complicated jurisdictional component, but also from the fact that wintertime ozone is a new discovery. Modern science is still grappling with the interaction of chemistry and geography that cause harmful ozone levels in the Basin.

Because traditional unilateral or bilateral problem solving sometimes fails to incorporate all the diverse interests of such a situation, the Uinta Basin presents an excellent opportunity for collaborative multi-stakeholder solutions. This paper addressed some of the background information relevant to ozone within the Basin, and then assessed the current situation through a stakeholder analysis. The suggested collaborative process in Part IV resulted from this analysis. It is but one possible way that air quality issues might be addressed within the Basin. However, forward progress probably requires some type of multi-stakeholder collaboration. Affirmative action is necessary to protect human health, and the Basin's future depends 
Uinta Basin: Elevated Ozone Creates Opportunities, Not Adversaries John Robinson Jr., April 2013 - Page 37

on successful resolution of the air quality dilemma. 